\title{
EFEKTIVITAS PELATIHAN ADVERSITY QUOTIENT UNTUK MENINGKATKAN MOTIVASI BERPRESTASI SISWA
}

\author{
Nabilah Panandrang Hasan ${ }^{1}$, Eva Meizara Puspita Dewi ${ }^{2}$, Ahmad Ridfah ${ }^{3}$ \\ 1,2,3Fakultas Psikologi Universitas Negeri Makassar \\ 1,2,3Kampus UNM Gunung Sari Jl. A.P. Pettarani, Makassar \\ Email: nabila.belahasan@gmail.com ${ }^{1}$, evabasti@yahoo.com ${ }^{2}$, ridfah@yahoo.com ${ }^{3}$
}

\begin{abstract}
Abstrak:
Motivasi berprestasi adalah dorongan yang dapat menggerakkan individu untuk bertingkah-laku mencapai suatu prestasi atau suatu kesuksesan sebagai tujuan yang diharapkan. Salah satu metode yang digunakan dalam meningkatkan motivasi berprestasi adalah pelatihan adversity quotient. Penelitian ini bertujuan untuk menguji efektivitas pelatihan adversity quotient dalam meningkatkan motivasi berprestasi siswa SMK X di Kota Makassar. Materi pelatihan yang diberikan adalah konsep diri, apa itu adversity quotient, konsep ABCDE dan CORE, problem solving dan analisis SWOT, tipe adversity quotient, serta aku bisa. Responden penelitian dipilih menggunakan teknik purposive sampling. Rancangan eksperimen menggunakan one group pre-test post-test design. Subjek penelitian ini berjumlah 15 orang. Penelitian ini menggunakan skala motivasi berprestasi yang didasarkan pada teori Mc Clelland dengan reliabilitas 0,820. Penelitian ini menggunakan teknik analisis data Wilcoxon Signed Rank Test yang kemudian diolah dengan SPSS version 20. Hasil penelitian ini menunjukkan bahwa pelatihan adversity quotient efektif dalam meningkatkan motivasi berprestasi siswa SMK X di Kota Makassar, dengan signifikansi sebesar 0,005.
\end{abstract}

\begin{abstract}
:
Achievement motivation is the drive that can move the individual to behave to achieve an achievement or a success as an expected goal. One of the methods used in improving achievement motivation is adversity quotient training. This study aims to test the effectiveness of adversity quotient training in improving the achievement motivation of students of SMK X in Makassar City. The training materials provided are self-concept, what is adversity quotient, $\mathrm{ABCDE}$ and CORE concept, problem solving and SWOT analysis, adversity quotient type, and I can. The respondents were chosen by using purposive sampling technique. The experimental design uses one group pre-test post-test design. Subjects of this study were 15 students. This research uses achievement motivation scale based on Mc Clelland theory with reliability 0,820 . This study uses Wilcoxon Signed Rank Test data analysis techniques which is then processed with SPSS version 20. The results of this study indicate that training adversity quotient is effective in improving student achievement motivation at SMK X Makassar at 0.005 level of significance.
\end{abstract}

Kata kunci:

Adversity Quotient, Motivasi Berprestasi, Siswa SMK

KEBERHASILAN pendidikan akan dicapai suatu bangsa apabila ada usaha untuk meningkatkan mutu pendidikan bangsa itu sendiri. Pendidikan adalah usaha sadar untuk menumbuh-kembangkan potensi sumber daya manusia (SDM). 
Gunarsa dan Gunarsa (2002) menjelaskan bahwa tolok ukur keberhasilan siswa dalam kegiatan pendidikan di sekolah selama ini ditunjukkan dengan prestasi akademik. Keberhasilan pada siswa sangat terkait dengan keberhasilannya pada prestasi akademik di sekolah. Prestasi sangat penting bagi siswa karena apabila siswa memiliki prestasi tentu akan memperoleh status pekerjaan yang lebih besar di masa yang akan datang. Dengan demikian, jelaslah bahwa prestasi merupakan sarana dalam melatih kesempatan yang pada akhirnya makin terbuka kesempatan dalam dunia pekerjaan dan sebaliknya, siswa yang memiliki prestasi rendah maka akan semakin kecil kesempatan yang dimilikinya dalam dunia pekerjaan.

Motivasi berprestasi merupakan daya dorong yang memungkinkan siswa berhasil mencapai apa yang diidamkan. Siswa yang memiliki motivasi berprestasi tinggi cenderung untuk selalu berusaha mencapai apa yang diinginkan, walaupun mengalami hambatan dan kesulitan dalam meraihnya. Motivasi berprestasi yang dimiliki seseorang idealnya selalu mengalami progresif atau kemajuan sehingga akan mempercepat apa yang diidamkan (Djaali, 2015).

Siswa yang memiliki permasalahan terkait motivasi berprestasi yang rendah juga dikeluhkan oleh salah satu sekolah swasta di Makassar. Berdasarkan hasil wawancara dengan guru BK di SMK X, pada tanggal 8 April 2016 diperoleh informasi bahwa siswa-siswa cenderung memiliki prestasi akademik yang rendah. Azwar (2013) menyatakan bahwa indikator siswa yang prestasi belajarnya tinggi yaitu memiliki nilai evaluasi belajar (prestasi) yang tinggi dan aktif dalam proses belajar. Data dari SMKX menunjukkan bahwa beberapa siswa memiliki nilai evaluasi belajar yang rendah dan pasif dalam proses pembelajaran di sekolah.

Hardjo dan Badjuri (2010) menyatakan dalam penelitiannya bahwa faktor yang sangat menentukan prestasi akademik adalah motivasi siswa itu sendiri untuk berprestasi. Siswa yang tidak ingin berprestasi, meskipun memiliki IQ yang tinggi prestasinya tidak akan meningkat. Penelitian tersebut juga mengungkapkan ada pengaruh positif antara motivasi berprestasi dengan prestasi akademik siswa.

Data yang diperoleh melalui wawancara guru BK dan wawancara dengan siswa menunjukkan bahwa penyebab utama dari rendahnya motivasi berprestasi siswa karena siswa tersebut menghindari pelajaran-pelajaran yang dianggap sulit untuk dikerjakan, seperti mata pelajaran yang menuntut berpikir lebih, pesimis dan mudah menyerah. Berdasarkan hasil analisis kebutuhan yang telah dilakukan siswa membutuhkan sebuah pelatihan untuk dapat meningkatkan motivasi berprestasi yang digunakan dalam menghadapi kesulitan, dalam kehidupan sehari-hari khususnya dalam prestasi akademik disekolah. Peneliti tertarik untuk membuat pelatihan adversity quotient agar siswa mampu menghadapi tantangan atau kesulitan-kesulitan yang dihadapi.

Adversity quotient (AQ) adalah kecerdasan seseorang dalam menghadapi situasisituasi masalah atau kemalangan dalam kehidupan. Hasil penelitian Vinas dan Malabanan (2015) yang dilakukan pada mahasiswa Philippines University menyatakan bahwa AQ dapat membantu siswa dalam mengatasi kesulitan yang terjadi, meningkat- 
kan kepercayaan diri dan motivasi yang kuat dalam proses pembelajaran. Stoltz (2000) menjelaskan bahwa adversity quotient (AQ) memiliki lima dimensi yaitu control, origin, ownership, reach, dan endurance.

Penelitian yang mendukung pengaruh pelatihan adversity quotient untuk meningkatkan motivasi berprestasi siswa juga dilakukan oleh Nurhayati dan Fajrianti (2014) dengan subjek 120 siswa SMA di Depok. Hasil penelitian tersebut menunjukkan bahwa terdapat pengaruh yang signifikan antara adversity quotient dan motivasi berprestasi terhadap prestasi belajar matematika.

Berdasarkan uraian di atas peneliti menggunakan pelatihan adversity quotient untuk meningkatkan motivasi berprestasi siswa SMK X di Kota Makassar, karena di dalam adversity quotient terdapat aspek-aspek yang dapat menentukan seseorang dalam menaruh harapan dan terus dapat memegang kendali dalam situasi yang sulit, yaitu control $(\mathrm{C})$, origin and ownership $(\mathrm{O} 2)$, reach $(\mathrm{R})$, dan endurance $(\mathrm{E})$.

\section{METODE PENELITIAN}

Variabel bebas dalam penelitian ini adalah Pelatihan adversity quotient merupakan bentuk pelatihan jangka pendek. Pelatihan ini terdiri atas enam materi, yaitu konsep diri akademik, apa itu adversity quotient, konsep ABCDE dan CORE, problem solving dan analisis SWOT, tipe adversity quotient, dan aku bisa. Variabel terikat dalam penelitian ini adalah motivasi berprestasi siswa yang dimaksudkan dalam penelitian ini merupakan dorongan yang dapat menggerakkan individu untuk bertingkah-laku mencapai suatu prestasi akademik di sekolah sebagai tujuan yang diharapkan. Tinggi rendahnya motivasi ini diungkap dengan skala motivasi berprestasi dengan menggunakan aspek-aspek dari Mc Clelland. Variabel control dalam penelitian ini adalah jenis kelamin, subjek yang digunakan berjenis kelamin perempuan.

Penelitian ini menggunakan rancangan eksperimental One group pre-test post-test design. awal penelitian dilakukan pengukuran tingkat motivasi berprestasi siswa, kemudian dua hari setelah pengukuran diberikan perlakuan berupa pelatihan. Satu minggu setelah pelatihan, pengukuran tingkat motivasi berprestasi kembali dilakukan dengan alat ukur yang sama.

Validitas pada penelitian ini menggunakan validitas isi dengan pengujian isi alat tes melalui penilaian dari validator ahli. Azwar (2015), rumus validitas yang digunakan ialah Aiken's V berfungsi untuk menghitung content-validity coefficient dan mengetahui sejauh mana aitem yang digunakan mewakili konstrak yang diukur. Penilaian diberikan menggunakan angka 1 sampai 5 . Angka 1 yaitu sangat tidak mewakili, hingga angka 5 yaitu sangat relevan.

Teknik analisis data menggunakan analisis deskriptif, Azwar (2015) menyatakan bahwa analisis deskriptif adalah menggambarkan data yang telah terkumpul. Analisis data dilakukan untuk memilih data yang kemudian dimasukkan dalam pengolahan statistik.

Hipotesis dalam penelitian ini dapat diketahui melalui proses membandingkan skor pre-test dan skor post-test peserta. Untuk mengetahui pengaruh pelatihan adver- 
sity quotient maka dibandingkan hasil skor tingkat motivasi berprestasi pada saat sebelum dan setelah mendapatkan perlakuan (pretest-posttest) dengan menggunakan analisis uji Wilcoxon.

\section{HASIL DAN PEMBAHASAN}

Hasil deskripsi subjek penelitian pada data penelitian diperoleh dari respon jawaban yang diisi oleh peserta pelatihan. Hasil respon jawaban pada skala motivasi berprestasi dapat dilihat bahwa lima belas subjek berada pada kategori motivasi berprestasi rendah pada saat pre-test. Deskripsi subjek penelitian berdasarkan peringkat yaitu subjek penelitian peringkat 31 sebanyak dua orang, peringkat 32 sebanyak dua orang, peringkat 33 sebanyak dua orang, peringkat 34 sebanyak tiga orang, peringkat 35 sebanyak tiga orang dan, peringkat 36 sebanyak tiga orang.

Tabel 1. Deskripsi subjek penelitian

\begin{tabular}{ccc}
\hline Ranking di kelas & Jumlah & Persentase \\
31 & 2 & $13,3 \%$ \\
32 & 2 & $13,3 \%$ \\
33 & 2 & $13,3 \%$ \\
34 & 3 & $20 \%$ \\
35 & 3 & $20 \%$ \\
36 & 3 & $20 \%$ \\
Total & 15 & $100 \%$ \\
\hline
\end{tabular}

Tabel 2. Deskripsi usia subjek penelitian

\begin{tabular}{ccc}
\hline Usia & Jumlah & Persentase \\
\hline 15 & 9 & $60 \%$ \\
16 & 6 & $40 \%$ \\
Total & 15 & $100 \%$ \\
\hline
\end{tabular}

Berdasarkan hasil wawancara dengan guru BK di SMK X, pada tanggal 8 April 2016 diperoleh informasi bahwa siswa-siswa cenderung memiliki prestasi akademik yang rendah hal ini ditandai dengan banyaknya siswa yang tidak menyenangi situasi yang menuntut tanggung jawab pribadi untuk menyelesaikan masalah, lebih tergantung pada orang lain, tidak memperdulikan hasil belajarnya, lebih sering berada di luar kelas jika pelajaran berlangsung, jika mengalami kegagalan akan selalu tertanam dalam pikirannya bahwa tidak mampu memperbaikinya (pesismis), tidak menyenangi mengambil resiko dan tantangan. Azwar (2013) menyatakan bahwa indikator siswa yang prestasi belajarnya tinggi yaitu memiliki nilai evaluasi belajar (prestasi) yang tinggi dan aktif dalam proses belajar, sedangkan data dari SMK X menunjukkan bahwa beberapa siswa memiliki nilai evaluasi belajar yang rendah dan pasif dalam proses pembelajaran di sekolah.

Pelatihan AQ dalam penelitian ini merupakan kegiatan yang dilakukan dengan memberi pengertian, pengetahuan, dan ketrampilan untuk memonitor, mengevaluasi, dan memodifikasi motivasi berprestasi yang dimiliki peserta, sehingga peserta da- 
pat mengaplikasikannya untuk meningkatkan prestasi belajar yang dimiliki. Dalam pelatihan ini lebih menekankan pada peningkatan motivasi berprestasi yang dimiliki siswa itu sendiri dengan terlebih dahulu meningkatkan AQ yang dimiliki siswa. Pelatihan yang dilaksanakan sekitar delapan jam ini terdiri atas enam materi.

Deskripsi evaluasi pelatihan adalah suatu alat untuk mengukur keefektifan dari suatu program pelatihan dengan menggunakan nilai hasil dari program. Evaluasi dalam pelatihan meliputi evaluasi peserta terhadap hasil evaluasi fasilitas, hasil observasi, hasil evaluasi materi, dan hasil evaluasi pemateri.

Hasil observasi peserta peserta didapatkan dari lembar observasi yang di isi oleh delapan orang observer. Tugas observer pada pelatihan ini, yaitu mengobservasi partisipasi peserta, perhatian peserta, dan inisiatif peserta pada saat pelatihan. Penilaian terdiri atas tiga kategori, yaitu: Nilai A apabila peserta memperoleh skor 7 ke atas, nilai $B$ apabila peserta memperoleh skor 4-6, dan nilai $C$ apabila peserta memperoleh skor 1-3. Adapun hasil dari observasi sebagai berikut:

Table 3. Observasi Peserta

\begin{tabular}{lccc}
\hline Subjek & Partisipasi peserta & $\begin{array}{c}\text { Perhatian } \\
\text { peserta }\end{array}$ & $\begin{array}{c}\text { Inisiatif } \\
\text { peserta }\end{array}$ \\
\hline NAR & $\mathrm{A}$ & $\mathrm{B}$ & $\mathrm{B}$ \\
CAR & $\mathrm{B}$ & $\mathrm{B}$ & $\mathrm{B}$ \\
AH & $\mathrm{A}$ & $\mathrm{A}$ & $\mathrm{A}$ \\
FD & $\mathrm{B}$ & $\mathrm{B}$ & $\mathrm{B}$ \\
YN & $\mathrm{B}$ & $\mathrm{B}$ & $\mathrm{B}$ \\
R & $\mathrm{B}$ & $\mathrm{B}$ & $\mathrm{A}$ \\
NST & $\mathrm{B}$ & $\mathrm{B}$ & $\mathrm{B}$ \\
PWAM & $\mathrm{B}$ & $\mathrm{A}$ & $\mathrm{B}$ \\
ANR & $\mathrm{B}$ & $\mathrm{B}$ & $\mathrm{A}$ \\
RBP & $\mathrm{B}$ & $\mathrm{A}$ & $\mathrm{B}$ \\
SSR & $\mathrm{A}$ & $\mathrm{A}$ & $\mathrm{A}$ \\
SR & $\mathrm{A}$ & $\mathrm{B}$ & $\mathrm{B}$ \\
NNA & $\mathrm{B}$ & $\mathrm{A}$ & $\mathrm{A}$ \\
FA & $\mathrm{A}$ & $\mathrm{B}$ & $\mathrm{B}$ \\
WA & $\mathrm{B}$ & $33,33 \%$ & $33,33 \%$ \\
Skor A & $33,33 \%$ & $66,67 \%$ & $66,67 \%$ \\
Skor B & $66,67 \%$ & & \\
\hline
\end{tabular}

Pada tabel 3, secara umum kategori subjek nampak berada pada kategori B. Peserta dengan nilai tertinggi yang mendapatkan skor pada setiap aspek yaitu AH, SR dan FA dengan skor A. Berdasarkan hasil evaluasi, menunjukkan bahwa subjek mengalami peningkatan motivasi berprestasi setelah pelatihan adversity quotient. Selain itu semua, peserta mengemukakan bahwa peserta lebih termotivasi dalam mengatasi masalah dan hambatan yang terjadi dalam mencapai tujuan untuk berprestasi.

Analisis deskriptif penelitian dideskripsikan melalui bentuk rata-rata empirik, standar deviasi, motivasi berprestasi minimum dan maksimum serta kategorisasi tingkat motivasi berprestasi pada subjekpenelitian. 
Tabel 4. Deskripsi data hipotetik skala motivasi berprestasi

\begin{tabular}{ccccc}
\hline & & & & Hipotetik \\
\cline { 2 - 5 } & Min & Max & Mean & SD \\
\hline $\begin{array}{c}\text { Motivasi } \\
\text { berprestasi }\end{array}$ & 26 & 104 & 65 & 13 \\
\hline
\end{tabular}

Tabel 5. Kategori motivasi berprestasi

\begin{tabular}{cc}
\hline Batas Kategori & Kategori \\
\hline $78-104$ & Tinggi \\
$52 \leq x<77$ & Sedang \\
$26-51$ & Rendah \\
\hline
\end{tabular}

Tabel 6. Kategorisasi respon skala motivasi berprestasi

\begin{tabular}{|c|c|c|c|c|c|}
\hline \multirow[t]{2}{*}{ No } & \multirow[t]{2}{*}{ Subjek } & \multicolumn{2}{|c|}{ Pre test } & \multicolumn{2}{|c|}{ Post test } \\
\hline & & Slsor & Kategari & Slsor & Kategari \\
\hline 1. & NAR & 42 & Rendah & 59 & Sedang \\
\hline 2 & CAR & 37 & Rendah & 64 & Sedang \\
\hline 3. & $\mathrm{AH}$ & 41 & Rendah & 61 & Sedang \\
\hline 4. & $\mathrm{FD}$ & 39 & Rendah & 65 & Sedang \\
\hline 5. & $\mathrm{YN}$ & 42 & Rendah & 60 & Sedang \\
\hline 6. & $\mathrm{R}$ & 38 & Rendah & 62 & Sedang \\
\hline 7. & NST & 41 & Rendah & 60 & Sedang \\
\hline 8. & PWAM & 41 & Rendah & 62 & Sedang \\
\hline 9. & ANR & 39 & Rendah & 58 & Sedang \\
\hline 10. & RBP & 39 & Rendah & 62 & Sedang \\
\hline 11. & SSR & 40 & Rendah & 67 & Sedang \\
\hline 12. & SR & 39 & Rendah & 57 & Sedang \\
\hline 13. & NNA & 31 & Rendah & 56 & Sedang \\
\hline 14. & FA & 40 & Rendah & 64 & Sedang \\
\hline 15. & WA & 38 & Rendah & 63 & Sedang \\
\hline
\end{tabular}

Pada tabel 6, dapat diketahui bahwa subjek penelitian yang berjumlah 15 orang siswa yang memiliki motivasi yang rendah di saat pre-test dan memiliki motivasi yang sedang di saat post-test

Tabel 7. Hasil uji hipotesis dengan Wilcoxon

\begin{tabular}{ccc}
\hline Kelompok & $\mathbf{p}$ & Keterangan \\
\hline Eksperimen & 0,005 & Signifikan \\
\hline
\end{tabular}

Hasil uji hipotesis menunjukkan bahwa hipotesis alternatif pada penelitian ini diterima, maka dengan demikian pelatihan adversity quotient efektif untuk meningkatkan motivasi berprestasi siswa SMK X di Kota Makassar. Data yang diperoleh menunjukkan bahwa adanya perbedaan nilai motivasi berprestasi antara pretest dan postest. Nilai pretest lebih kecil dari pada nilai post-test. Hal ini sejalan dengan penelitian yang dilakukan oleh Utami, Nashori, dan Rachmawati (2014) dengan subjek 32 siswa SMP di Yogyakarta. Penelitian tersebut bertujuan untuk mengetahui pengaruh 
pelatihan adversity quotient terhadap motivasi belajar siswa. Hasil penelitian tersebut menunjukkan bahwa ada perbedaan tingkat motivasi belajar antara sebelum dan setelah diberi pelatihan adversity quotient.

Tabel 8. Hasil perbandingan pretest dan posttest tes pengetahuan

\begin{tabular}{ccc}
\hline Kelompok & $\mathbf{p}$ & Keterangan \\
\hline Eksperimen & 0 & Signifikan \\
\hline
\end{tabular}

Berdasarkan hasil pengujian Wilcoxon pada tes pengetahuan mengenai materi pelatihan diperoleh hasil signifikansi 0 yang diketahui lebih kecil dari 0,05. Dengan hasil tersebut, maka terdapat perbedaan yang sangat signifikan antara skor pre-test dan post-test pada tes pengetahuan, dimana apabila diberikan perlakuan berupa pelatihan adversity quotient terdapat perbedaan sebelum dan setelah pelatihan. Perbedaan skor pre-test dan post-test pada tes pengetahuan karena dalam pelatihan adversity quotient dalam penelitian ini merupakan kegiatan yang dilakukan dengan memberi pengertian, pengetahuan, dan memodifikasi motivasi berprestasi yang dimiliki peserta sehingga peserta dapat mengaplikasikannya untuk meningkatkan motivasi berprestasi. Penelitian yang mendukung pengaruh adversity quotient untuk meningkatkan motivasi berprestasi siswa juga dilakukan oleh Nurhayati dan Fajrianti (2014), dengan subjek 120 siswa SMA di Depok. Hasil penelitian tersebut menunjukkan bahwa terdapat pengaruh yang signifikan antara adversity quotient dan motivasi berprestasi terhadap prestasi belajar matematika.

\section{KESIMPULAN}

Ada perbedaan motivasi berprestasi siswa sebelum mengikuti pelatihan adversity quotient (pre-test) dan setelah mengikuti pelatihan adversity quotient (post-test). Dimana skor motivasi berprestasi meningkat setelah siswa mengikuti pelatihan. Hasil evaluasi menunjukkan tingkat kepuasan siswa yang tinggi. Dari hasil tersebut, siswa merasa puas terhadap materi, pemateri, modul, fasilitas yang diberikan selama pelatihan adversity quotient.

\section{DAFTAR PUSTAKA:}

Altalib, H. Y. (1991). Training Guide for Islamic Workers. Herndon: The International Institute of Islamic Thought.

Azwar, S. (2013). Tes Prestasi. Yogyakarta: Pustaka Pelajar.

Azwar, S. (2015). Penyusunan Skala Psikologi. Yogyakarta: Pustaka Pelajar.

Chaplin, J.P. (1997). Kamus Lengkap Psikologi, (Terjemahan dari Dr. Kartini Kartono). Jakarta: PT. Raja Grafindo Persada.

Djaali. (2015). Psikologi Pendidikan. Jakarta. PT Bumi Aksara.

Goldstein, E.B. (1994). Psychology. California: Brooks/cole Publishing Company.

Gunarsa, S. D., \& Gunarsa, Y. S. D. (2002). Psikologi Perkembangan Anak dan Remaja. Jakarta: PT. BPK Gunung Mulia. 
Hadi, S. (2001). Statistic Jilid 2: Yogyakarta: Andi.

Hardjo, S., \& Badjuri. (2010). Pengaruh Motivasi Berprestasi dan Cara Belajar terhadap Prestasi Belajar Siswa Sekolah Dasar di Kabupaten Semarang. Jurnal Pendidikan, 1(2): 12-24, 2010.

Hasanah, N., Zulhelmi., \& Azizahwati. (2015). Perbedaan Motivasi Belajar Siswa Berdasarkan Gender dalam Pembelajaran Fisika dengan Model Collaborative Learning di Kelas X Madrasah Aliyah Al-Ihsan Boarding School Kampar. Physic Education Study Program.

Kirkpatrick, D. L., \& Krikpatrick, J. D. (2005). Evaluating Training Programs. San Fransisco: Berret-Koehler Publisher Inc.

Kusuma, I. H. (2004). Studi Korelasional antara Kecerdasan Adversity dan Motivasi Berprestasi dengan Kinerja Kepala Sekolah di Lingkungan Yayasan BPK PENABUR Jakarta. Jurnal Pendidikan Penabur, 2(3).

McClelland, D. C. (1987). Human Motivation. New York: Cambridge University Press.

Morgan, Clifford, T., King, Richard, A., Weisz, John, R., \& Schopler, John. (1986). Introduction to Psychology, Toronto: Mc Graw-Hill.

Noe, R. A. (2010). Employee Training and Development, Library of Congress Cataloging in Publication Data, Mcgraw-Hill.

Nurhayati \& Fajrianti, N. (2014). Pengaruh Adversity Quotient (AQ) dan Motivasi Berprestasi terhadap Prestasi Belajar Matematika. Jurnal Formatif, 3(1), 72-77.

Seniati, L., Yulianto, A. \& Setiadi, B. N. (2011). Psikologi Eksperimen, Jakarta: Indeks.

Stoltz, P.G. (2000). Adversity Quotient: Mengubah Hambatan Menjadi Peluang. Jakarta: PT Gramedia Widiasarana Indonesia.

Sugiyanto. (2009). Kontribusi Motivasi Berprestasi terhadap Prestasi Akademik Siswa Kelas XI SMA Negeri 10 Semarang. Jurnal Paradigma, 08(IV):19-34, 2009..

Suryabrata, S. (2013). Metodelogi Penelitian, Jakarta: Rajawali Pers.

Undang-undang Sistem Pendidikan Nasional No.20 Tahun 2003. Diakses pada 28 April 2016. Indonesia. www.depdagri.go.id.

Utami, S., Nashori. H. F., \& Rachmawati, M. A. (2014). Pengaruh Pelatihan Adversity Quotient untuk Meningkatkan Motivasi Belajar Siswa Sekolah Menengah Pertama. Jurnal Intervensi Psikologi, 6(1), 131-149, 2014.

Vinas, D. K. D., \& Malabanan, M. G. A. (2015). Adversity Quotient and Coping Strategies of College Students in Lyceum of the Philippines University. Asia Pacific Journal of Education, Arts and Sciences, 2(3), 68-72, 2015.

Wardiana, A. P., Wiarta, W., \& Zulaikha, S. (2014). Hubungan antara Adversity Quotient (AQ) dan Minat Belajar dengan Prestasi Belajar Matematika pada Siswa Kelas V SD di Kelurahan Pedungan. Jurnal Mimbar PGSD Universitas Pendidikan Ganesha, 1 (2), 2014.

Widyaningrum, J., \& Rachmawati, M. A. (2007). Adversity Intelligence dan Prestasi Belajar Siswa Semarang. Jurnal Psikologi Proyeksi, 2(2), 45-53, 2007. 